\title{
Clear Cell Squamous Cell Carcinoma of the Penis
}

National Cancer Institute

\section{Source}

National Cancer Institute. Clear Cell Squamous Cell Carcinoma of the Penis. NCI

Thesaurus. Code C159251.

A squamous cell carcinoma of the penis. It is characterized by the presence of malignant cells with clear cytoplasm. 